\title{
Gas Exchange and Mineral Nutrition of 12 Viburnum Taxa Irrigated with Saline Water
}

\author{
Ji Jhong Chen \\ Department of Plants, Soils, and Climate, Utah State University, 4820 Old \\ Main Hill, Logan, UT 84322
}

Haifeng Xing

College of Grassland Resources and Environment, Inner Mongolia Agricultural University, Hohhot, Inner Mongolia 010010, China

Asmita Paudel and Youping Sun

Department of Plants, Soils, and Climate, Utah State University, 4820 Old Main Hill, Logan, UT 84322

\section{Genhua Niu}

Department of Horticultural Sciences, Texas A\&M AgriLife Research Center at Dallas, Texas A\&M University, 17360 Coit Road, Dallas, TX 75252

\section{Matthew Chappell \\ Department of Horticulture, University of Georgia, 326 Hoke Smith Building, Athens, GA 30602}

Additional index words. chloride, landscape plant, photosynthesis, salinity, sodium, stomatal conductance, transpiration rate

\begin{abstract}
More than half of residential water in Utah is used for landscape irrigation. Reclaimed water has been used to irrigate urban landscapes to conserve municipal water. High salt levels in reclaimed water may pose osmotic stress and ion toxicity to saltsensitive plants. Viburnums are commonly used landscape plants, but salinity tolerance of species and cultivars is unclear. The objective of this study was to characterize gas exchanges and mineral nutrition responses of 12 viburnum taxa subjected to salinity stress in a greenhouse study. Plants were irrigated with a nutrient solution at an electrical conductivity (EC) of $1.3 \mathrm{dS} \cdot \mathrm{m}^{-1}$ or saline solution at an $\mathrm{EC}$ of $5.0 \mathrm{dS} \cdot \mathrm{m}^{-1}$ or $10.0 \mathrm{dS} \cdot \mathrm{m}^{-1}$. The net photosynthesis rate $\left(\mathrm{P}_{n}\right)$, stomatal conductance $\left(g_{S}\right)$, and transpiration rate $(E)$ of all viburnum taxa, except for Viburnum $\times$ burkwoodii and $V . \times$ 'NCVX1', decreased to various degrees with increasing salinity levels. The $P_{n}, g_{S}$, and $E$ of $V . \times$ burkwoodii and $V$. $X$ 'NCVX1' were unaffected by saline solutions of $5.0 \mathrm{dS} \cdot \mathrm{m}^{-1}$ at the 4 th and 9 th week after treatment initiation, with the exception of the $P_{n}$ of $V . \times$ burkwoodii, which decreased at the 9th week. Leaf sodium $\left(\mathrm{Na}^{+}\right)$and chloride $\left(\mathrm{Cl}^{-}\right)$concentrations of all viburnum taxa increased as salinity levels increased. Viburnum $\times$ burkwoodii had relatively low leaf $\mathrm{Na}^{+}$ and $\mathrm{Cl}^{-}$when irrigated with saline solutions of $10.0 \mathrm{dS} \cdot \mathrm{m}^{-1}$. Plant growth and gas exchange parameters, including visual score, plant height, $P_{n}, g_{S}, E$, and water use efficiency (WUE) correlated negatively with leaf $\mathrm{Na}^{+}$and $\mathrm{Cl}^{-}$concentrations. The ratio of potassium $\left(\mathrm{K}^{+}\right)$to $\mathrm{Na}^{+}\left(\mathrm{K}^{+} / \mathrm{Na}^{+}\right)$and ratio of calcium $\left(\mathrm{Ca}^{2+}\right)$ to $\mathrm{Na}^{+}\left(\mathrm{Ca}^{2+} / \mathrm{Na}^{+}\right)$decreased when salinity levels increased. Visual score, plant height, $P_{n}, g_{S}, E$, and WUE correlated positively with the $\mathrm{K}^{+} / \mathrm{Na}^{+}$and $\mathrm{Ca}^{2+} / \mathrm{Na}^{+}$ratios. These results suggest excessive $\mathrm{Na}^{+}$and $\mathrm{Cl}^{-}$accumulation inhibited plant photosynthesis and growth, and affected $\mathrm{K}^{+}$and $\mathrm{Ca}^{2+}$ uptake negatively.
\end{abstract}

Salinity has become a serious abiotic stressor in both nursery production and urban landscapes. Irrigating with poor-quality water and overapplication of fertilizer, manure, and compost in nursery production can lead to salt accumulation in poorly drained soils and can cause overaccumulation of salinity within the rhizosphere (Daliakopoulos et al., 2016). In arid and semiarid regions, low precipitation and high evaporation causes salts to accumulate at the soil surface, which induces salinity stress, leading to reductions in plant growth. According to a survey con- ducted by the Utah Division of Water Resource (2014), 65\% of residential water is used for landscape irrigation. As a result of rapid population growth and ever-decreasing water resources, Utah would consider using treated and reclaimed municipal effluent (reclaimed or gray water) and industrial wastewater for landscape irrigation (Utah Division of Water Resources, 2005). Reclaimed water typically has high salt levels that decrease water potential and may contribute to plants experiencing osmotic stress, even when soil moisture is adequate for plant growth and development. Salts in reclaimed water also incur specific ionic effects on landscape plants as a result of preferential uptake or uptake pathway blockage.

Osmotic stress and ion toxicity disturb plant growth and development (Taiz et al., 2015). Osmotic stress limits water availability and can pose a rapid threat to plant growth, whereas excessive accumulation of $\mathrm{Na}^{+}$and $\mathrm{Cl}^{-}$ions causes ion toxicity over a longer timeframe (Munns and Tester, 2008; Taiz et al., 2015). Physiologically, salinity affects net photosynthesis, $g_{\mathrm{S}}$, and E negatively, leading to reduced plant growth (Cai et al., 2014; Liu et al., 2017; Sun et al., 2015). Furthermore, salinity-induced nutritional disorders are common. High $\mathrm{Na}^{+}$and $\mathrm{Cl}^{-}$levels are associated with decreased $\mathrm{K}^{+}$concentrations in plant leaves that lead to $\mathrm{K}^{+}$deficiency (Sun et al., 2015; Taiz et al., 2015; Wu et al., 2016). Salinity also affects the uptake and accumulation of phosphorus $(\mathrm{P})$ and $\mathrm{Ca}^{2+}$ negatively, resulting in $\mathrm{P}$ and $\mathrm{Ca}^{2+}$ deficiency in plants under salinity stress (Grattan and Grieve, 1999). However, salinity-induced nutrient disorders vary widely among plant taxa. Therefore, it is critically important to understand the effects of salinity stress on mineral nutrient status of ornamental plant species grown in sodic soils.

Osmotic adjustment, ion exclusion, and internal tolerance are mechanisms that facilitate adaption to high-salinity situations. Plants capable of osmotic adjustment can produce compatible solutes such as glycine betaine, organic sugar, and proline in cytosol, and accumulate these compatible solutes in the vacuole under salinity stress (Taiz et al., 2015). In addition, ion exclusion and internal tolerance can help plants tolerate ion toxicity and prevent toxic ions from disturbing plant metabolism (Munns and Tester, 2008). Ion exclusion is a mechanism by which plant roots minimize ion absorption (into root sheath cells) that would subsequently be xylem-loaded to accumulate in other tissues. Internal tolerance includes biochemical adaptation that affords plants the ability to compartmentalize, or chelate, elevated levels of toxic ions (Munns, 2002; Taiz et al., 2015). For example, Delosperma cooperi (hardy ice plant) was determined to exclude $\mathrm{Na}^{+}$in its shoots effectively and tolerate high $\mathrm{Cl}^{-}$in plant cells (Niu and Rodriguez, 2006). Sedum telephium (orpine) treated with saline solutions accumulated high $\mathrm{K}^{+}$that may associate with osmotic adjustment (Hooks and Niu, 2019). Another study found that leaf $\mathrm{K}^{+}$ concentration of Aloe vera (barbados aloe) and Gazania rigens (syn. G. splendens) (gazania, treasure flower) decreased as a result of $\mathrm{Na}^{+}$competing for the transport system when salinity levels were elevated from 2.0 to 7.5 $\mathrm{dS} \cdot \mathrm{m}^{-1}$. Leaf $\mathrm{K}^{+}$of Kalanchoe blossfeldiana (kalanchoe) was unaffected by saline solution (García-Caparrós et al., 2016).

The genus Viburnum belongs to Adoxaceae (the moschatel family) and includes about 175 species. Viburnums are widely used in American and European landscapes. An estimated three million viburnum plants 
are sold annually in the United States, with a wholesale value of more than USD 22 million (Pooler, 2010). Viburnums can tolerate various environmental stresses. Kollmann and Grubb (2002) reviewed the responses of viburnum plants to freezing, drought, and flooding stresses, yet knowledge of salinity tolerance is limited. According to Beckerman and Lerner (2015), some viburnum taxa are sensitive to salt spray. In another study, when irrigated with a saline solution of $6.0 \mathrm{dS} \cdot \mathrm{m}^{-1}$, $V$. tinus (laurustinus) plants were shorter and had decreased $g_{\mathrm{S}}$ compared with those irrigated with water $\left(\mathrm{EC}<0.9 \mathrm{dS} \cdot \mathrm{m}^{-1}\right)(\mathrm{Gómez}-$ Bellot et al., 2018). However, Cassaniti et al. (2009) suggested that $V$. tinus 'Lucidum' (laurustinus) plants were tolerant to salinity levels at ECs of 4.4 and $7.4 \mathrm{dS} \cdot \mathrm{m}^{-1}$. The objective of our study was to investigate the effects of saline solution irrigation on the physiological responses and mineral nutrition status of 12 viburnum taxa.

\section{Materials and Methods}

Plant materials and treatments. The experiment was conducted in a research greenhouse at Utah State University in Logan, UT. Twelve viburnum taxa were used in the study: Viburnum xburkwoodii (burkwood viburnum), $V$. cassinoides 'SMNVCDD' (Lil' Ditty ${ }^{\circledR}$ witherod viburnum, USPP 27549), V. dentatum 'Christom' (Blue Muffin ${ }^{\circledR}$ arrowwood viburnum), $V$. dentatum var. deamii 'SMVDLS' (All That Glitters ${ }^{\circledR}$ ar-

Received for publication 18 Feb. 2020. Accepted for publication 27 Apr. 2020.

Published online 8 July 2020

This research was supported in part by the U.S. Department of Agriculture (USDA) National Institute of Food and Agriculture Hatch project UTA01381 and TEX090450 and USDA Specialty Crop Block Grant Program (no. 202715), New Faculty Start-Up Funds from the Office of Research and Graduate Studies, the Center for Water-Efficient Landscaping, and the Utah Agricultural Experiment Station (UAES) at Utah State University. This research was also supported by the Center for Applied Nursery Research, a nonprofit research center located in Dearing, GA. It is approved as UAES journal paper no. 9327. We appreciate the financial support from China Scholarship Council to Haifeng Xing as a visiting scholar at Utah State University, Logan, UT. We are grateful for the in-kind support of plant materials from Spring Meadow Nursery (Grand Haven, MI), chloride analyses from Christina Perez, and valuable comments from anonymous reviewers. The content is solely the responsibility of the authors and does not necessarily represent the official views of the funding agencies. Mention of a trademark, proprietary product, or vendor does not constitute a guarantee or warranty of the product by the USDA or the American Society for Horticultural Science and does not imply its approval to the exclusion of other products or vendors that also may be suitable.

Y.S. is the corresponding author. E-mail: youping. sun@usu.edu.

This is an open access article distributed under the CC BY-NC-ND license (https://creativecommons.org/ licenses/by-nc-nd/4.0/). rowwood viburnum, USPP 26576), $V$. dilatatum 'Henneke' (Cardinal Candy ${ }^{\circledR}$ linden viburnum, USPP 12870), V. ×'NCVX1' (Shiny Dancer ${ }^{\circledR}$ viburnum, USPP 28095), $V$. nudum 'Bulk' (Brandywine ${ }^{\mathrm{TM}}$ witherod viburnum), $V$. opulus 'Roseum' (European cranberrybush viburnum), $V$. plicatum var. tomentosum 'Summer Snowflake' (doublefile viburnum), V. pragense 'Decker' (Prague viburnum), $V$. Xrhytidophylloides 'Redell' (Red Balloon ${ }^{\circledR}$ lantanaphyllum viburnum, USPP 24227), and $V$. trilobum (Redwing ${ }^{\circledR}$ American cranberrybush viburnum). On 7 Feb. 2019 , rooted cuttings $(\approx 6 \mathrm{~cm}$ tall) were received from Spring Meadow Nursery (Grand Haven, MI). One week later, viburnum cuttings were transplanted into $3.8-\mathrm{L}$ injection-molded, polypropylene containers (PC1D-4; Nursery Supplies, Orange, CA) filled with soilless media. The soilless media consisted of $75 \%$ peatmoss (Canadian sphagnum peatmoss; SunGro Horticulture, Agawam, MA), 25\% vermiculite (Therm-ORock West, Chandler, AZ), $0.86 \mathrm{~kg} \cdot \mathrm{m}^{-3}$ white athletic field marking gypsum $(92 \%$ calcium sulfate dihydrate, $21 \%$ calcium, $17 \%$ sulfur; Western Mining and Minerals, Bakersfield, CA), $9 \mathrm{~kg} \cdot \mathrm{m}^{-3}$ dolomitic lime (Lhoist North America, Salinas, CA), and $0.59 \mathrm{~kg} \cdot \mathrm{m}^{-3}$ wetting agent (AquaGro 2000G; Aquatrols, Paulsboro, NJ). On 26 Mar. 2019, plants were sorted into 10 blocks, each with three uniform plants per taxon, for the experiment with the exception of $V$. ' $^{\text {NCVX1', of }}$ which six blocks were used. Viburnum opulus 'Roseum' and V. trilobum were pruned to $20 \mathrm{~cm}$ high. Bifenthrin (Talstar ${ }^{\circledR}$; FMC Corporation, Philadelphia, PA) at $7.8 \mathrm{~mL} \cdot \mathrm{L}^{-1}$ was sprayed to control spider mites (Oligonychus ilicis) as needed. Environmental conditions and additional experimental details are included in the companion article (Sun et al., 2020).

On 28 Mar. 2019, a nutrient solution at an EC of $1.3 \mathrm{dS} \cdot \mathrm{m}^{-1}$ or saline solutions at ECs of 5.0 or $10.0 \mathrm{dS} \cdot \mathrm{m}^{-1}$ were applied to the plants. Tap water was mixed with a water-soluble fertilizer $15 \mathrm{~N}-2.2 \mathrm{P}-12.5 \mathrm{~K}$ (Peters $15-5-15$ Cal-Mag Special; Scotts, Marysville, $\mathrm{OH}$ ) at $0.8 \mathrm{~g} \cdot \mathrm{L}^{-1}$ to make the nutrient solution (control), and the EC of the nutrient solution was $1.31 \pm 0.08 \mathrm{dS} \cdot \mathrm{m}^{-1}$ (mean $\pm \mathrm{SD}$ ) during the experiment. Sodium chloride $(\mathrm{NaCl}$; Fisher Scientific, Waltham, MA) at $0.92 \mathrm{~g} \cdot \mathrm{L}^{-1}$ and dihydrate calcium chloride $\left(\mathrm{CaCl}_{2} \cdot 2 \mathrm{H}_{2} \mathrm{O}\right.$; $\mathrm{Hi}$ Valley Chemical, Centerville, UT) at 1.17 $\mathrm{g} \cdot \mathrm{L}^{-1}$ were added to the nutrient solution to prepare the saline solution at ECs of $5.07 \pm$ $0.04 \mathrm{dS} \cdot \mathrm{m}^{-1}$. The saline solution at ECs of $10.08 \pm 0.04 \mathrm{dS} \cdot \mathrm{m}^{-1}$ was prepared by adding $2.27 \mathrm{~g} \cdot \mathrm{L}^{-1} \mathrm{NaCl}$ and $2.88 \mathrm{~g} \cdot \mathrm{L}^{-1} \mathrm{CaCl}_{2} \cdot 2 \mathrm{H}_{2} \mathrm{O}$ to the nutrient solution. Nitric acid at 1 $\mathrm{mol} \cdot \mathrm{L}^{-1}$ was used to adjust the $\mathrm{pH}$ to 6.0 for all treatment solutions. Treatment solutions were applied once a week, eight times in total. Before each treatment, the ECs of all treatment solutions were recorded using an EC meter (Horiba, Kyoto, Japan). Plants received $1 \mathrm{~L}$ of treatment solution at each treatment, and the leaching fraction was $33.2 \%$. On 27 Apr. 2019 (4 weeks after the initiation of treatment), five plants of 10 blocks were harvested destructively (first harvest) with the exception of $V . \times$ 'NCVX1', because all plants had no foliar salt damage. On 31 May 2019 ( 9 weeks after the initiation of treatment), the remaining plants were harvested (second harvest).

Visual score and plant growth. Visual score and plant growth data were recorded before harvest. Each plant was evaluated for visual quality by assigning a visual score of 0 to 5 , where $0=$ dead, $1=$ severe foliar salt damage ( $>90 \%$ leaves with burn and necrosis), $2=$ moderate foliar salt damage $(90 \%$ to $50 \%), 3=$ slight foliar salt damage $(<50 \%), 4$ $=$ good quality with minimal foliar salt damage, and $5=$ excellent without foliar salt damage (Sun et al., 2015). Plant height (centimeters) was recorded at the beginning of the treatments and at both harvest dates, and plant height increment was calculated as the differences between the initial height and the height at each harvest date. Leaf area was recorded using a leaf area meter (LI-3100; LI-COR Biosciences, Lincoln, NE), and shoot dry weight was recorded when shoots were dried in an oven at $80^{\circ} \mathrm{C}$ for $4 \mathrm{~d}$. These visual quality and growth data are presented in the companion article (Sun et al., 2020).

Gas exchange. Leaf $\mathrm{P}_{\mathrm{n}}, g_{\mathrm{S}}, E$, and WUE were recorded $2 \mathrm{~d}$ before the first and second harvest. Four plants per taxa per treatment were selected randomly for gas exchange measurements from 10 and five plants at the first harvest and the second harvest, respectively. These measurement criteria were repeated for all taxa with the exception of $V$. $\times$ 'NCVX1', for which four out of six plants were measured at both harvest dates. Gas exchange was measured on a sunny day between 1000 and 1400 HR using a portable photosynthesis system with a PLC3 universal leaf cuvette (CIRAS-3; PP Systems, Amesbury, MA). A healthy, mature leaf on each plant was selected randomly for gas exchange measurement. The photosynthetic photon flux density within the cuvette was applied at $1000 \mu \mathrm{mol} \cdot \mathrm{m}^{-2} \cdot \mathrm{s}^{-1}$ with $38 \%$ red, $37 \%$ green, and $25 \%$ blue light provided from light-emitting diodes, whereas the carbon dioxide $\left(\mathrm{CO}_{2}\right)$ and leaf temperature were set at $400 \mu \mathrm{mol} \cdot \mathrm{mol}^{-1}$ and $25^{\circ} \mathrm{C}$, respectively.

Mineral analyses. Leaves of all viburnum taxa at the first harvest were used for analyzing $\mathrm{Na}^{+}, \mathrm{Cl}^{-}, \mathrm{Ca}^{2+}$, and $\mathrm{K}^{+}$concentrations, with the exception of $V$. $\times^{\text {'NCVX1', for }}$ which leaves at the second harvest were used. Four plants per taxa per treatment out of five blocks (six blocks for $V . \times^{\prime} \mathrm{NCVX} 1$ ') were sampled randomly for mineral analyses. Dried leaves were ground using a stainless Thomas-Wiley laboratory mill (model 4; Thomas Scientific, Swedesboro, NJ) with a $1-\mathrm{mm}$ mesh screen. Samples were extracted with $2 \%$ acetic acid (EM Science, Gibbstown, $\mathrm{NJ}$ ) to determine $\mathrm{Cl}^{-}$content (Gavlak et al., 1994). An M926 Chloride Analyzer (Cole Parmer Instrument Company, Vernon Hills, IL) was used to determine the concentration of $\mathrm{Cl}^{-}$. When assessing $\mathrm{Na}^{+}, \mathrm{Ca}^{2+}$, and $\mathrm{K}^{+}$content, samples were sent to the Soil, 
Table 1. Net photosynthesis rate $\left(\mathrm{P}_{\mathrm{n}}\right)$ of 12 viburnum taxa irrigated with a nutrient solution [electrical conductivity $(\mathrm{EC})=1.3 \mathrm{dS} \cdot \mathrm{m}^{-1} ;$ control] or a saline solution $\left[\mathrm{EC}=5.0 \mathrm{dS} \cdot \mathrm{m}^{-1}(\mathrm{EC} 5)\right.$ or $\left.10.0 \mathrm{dS} \cdot \mathrm{m}^{-1}(\mathrm{EC} 10)\right]$ in a greenhouse. ${ }^{\mathrm{z}}$

\begin{tabular}{|c|c|c|c|c|c|c|}
\hline \multirow{2}{*}{ Taxa } & \multicolumn{6}{|c|}{$\mathrm{P}_{\mathrm{n}}, \mu \mathrm{mol} \mathrm{CO} \mathrm{CO}_{2} \cdot \mathrm{m}^{-2} \cdot \mathrm{s}^{-1}$} \\
\hline & \multicolumn{3}{|c|}{ First harvest } & \multicolumn{3}{|c|}{ Second harvest } \\
\hline Viburnum $\times$ burkwoodii & $6.3 \mathrm{a}^{\mathrm{y}}$ & $5.4 \mathrm{ab}$ & $3.0 \mathrm{~b}$ & $5.3 \mathrm{a}$ & $3.0 \mathrm{~b}$ & $1.4 \mathrm{~b}$ \\
\hline V. dentatum 'Christom' & $5.3 \mathrm{a}$ & $4.3 \mathrm{a}$ & $1.6 \mathrm{~b}$ & $2.9 \mathrm{a}$ & $1.5 \mathrm{~b}$ & - \\
\hline V. dentatum var. deamii 'SMVDLS' & $6.0 \mathrm{a}$ & $3.7 \mathrm{~b}$ & $2.0 \mathrm{~b}$ & $3.5 \mathrm{a}$ & $1.3 \mathrm{~b}$ & - \\
\hline V. dilatatum 'Henneke' & $3.4 \mathrm{a}$ & $2.2 \mathrm{a}$ & $-^{x}$ & 0.8 & - & - \\
\hline$V . x^{\circ} \mathrm{NCVX} 1{ }^{\prime}$ & $2.1 \mathrm{a}$ & $1.7 \mathrm{a}$ & $1.3 \mathrm{a}$ & $2.2 \mathrm{a}$ & $1.3 \mathrm{ab}$ & $0.3 \mathrm{~b}$ \\
\hline V. plicatum var. tomentosum 'Summer Snowflake' & $9.7 \mathrm{a}$ & $5.7 \mathrm{~b}$ & $1.3 \mathrm{c}$ & $4.7 \mathrm{a}$ & $3.2 \mathrm{~b}$ & - \\
\hline V. pragense 'Decker' & $7.7 \mathrm{a}$ & $5.4 \mathrm{~b}$ & $3.6 \mathrm{~b}$ & $5.9 \mathrm{a}$ & $2.7 \mathrm{~b}$ & - \\
\hline V. ×rhytidophylloides 'Redell' & $8.6 \mathrm{a}$ & $3.2 \mathrm{~b}$ & $1.8 \mathrm{~b}$ & $4.4 \mathrm{a}$ & $1.7 \mathrm{~b}$ & - \\
\hline V. trilobum & $7.2 \mathrm{a}$ & $3.0 \mathrm{~b}$ & - & $3.8 \mathrm{a}$ & $1.5 \mathrm{~b}$ & - \\
\hline
\end{tabular}

${ }^{\mathrm{z}}$ Plants were harvested after the fourth irrigation (first harvest, four weeks after the initiation of treatment) and eighth irrigation (second harvest, nine weeks after the initiation of treatment).

${ }^{\mathrm{y}}$ Means with the same lowercase letters within a row and harvest date are not significantly different among treatments by Tukey's honestly significant difference test or between treatments with Student's $t$ test at $\alpha=0.05$.

${ }^{\mathrm{x}}$ Data were not collected due to plant death.

Water, and Forage Testing Laboratory at Texas A\&M University (College Station, $\mathrm{TX}$ ) and were digested in $70 \%$ to $71 \%$ concentrated nitric acid (Havlin and Soltanpour, 1980). A coupled plasma-optical emission spectrometer (SPECTRO Analytical Instruments, Mahwah, NJ) was used to analyze $\mathrm{Na}^{+}, \mathrm{Ca}^{2+}$, and $\mathrm{K}^{+}$in the digest samples and results are reported on a dry biomass basis (Isaac and Johnson, 1975). The $\mathrm{K}^{+} / \mathrm{Na}^{+}$and $\mathrm{Ca}^{2+} / \mathrm{Na}^{+}$ratios were calculated by dividing the $\mathrm{K}^{+}$or $\mathrm{Ca}^{2+}$ concentration by the $\mathrm{Na}^{+}$ concentration.

Experimental design and statistical analyses. A randomized complete block design with 10 blocks for all taxa, except six

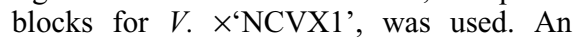
analysis of variance procedure was used to test effects of salinity on gas exchange parameters as well as effects of salinity and taxa (except for $V$. ×'NCVX1') on mineral nutrient concentrations. Means separation among or between treatments was conducted using Tukey's honestly significant difference multiple comparisons or Student's $t$ test at $\alpha=$ 0.05 . Correlation analyses were also conducted among visual scores, plant growth, gas exchange parameters, and $\mathrm{Na}^{+}$and $\mathrm{Cl}^{-}$concentrations as well as $\mathrm{K}^{+} / \mathrm{Na}^{+}$and $\mathrm{Ca}^{2+} / \mathrm{Na}^{+}$ ratios. All statistical analyses were performed using JMP software (Version 13.2; SAS Institute, Cary, NC).

\section{Results and Discussion}

\section{Gas exchange}

At the first harvest, compared with the control, a saline solution of $5.0 \mathrm{dS} \cdot \mathrm{m}^{-1}$ inhibited the $\mathrm{P}_{\mathrm{n}}$ of $V$. cassinoides 'SMNVCDD', $V$. dentatum var. deamii 'SMVDLS', V. nudum 'Bulk', V. plicatum var. tomentosum 'Summer Snowflake', $V$. pragense 'Decker', V. ×rhytidophylloides 'Redell', and V. trilobum by $30 \%$ to $62 \%$. Conversely, a saline solution of $10.0 \mathrm{dS} \cdot \mathrm{m}^{-1}$ decreased the $\mathrm{P}_{\mathrm{n}}$ of all viburnum taxa by $53 \%$ to $90 \%$, except for $V$. $\times$ 'NCVX1' (Table 1). At the second harvest, all viburnum taxa except for $V$. $\times{ }^{\prime} \mathrm{NCVX} 1$ ' and $V$. nudum 'Bulk' had $\mathrm{P}_{\mathrm{n}}$ reductions of $33 \%$ to $73 \%$ when irrigated with a saline solution of 5.0 $\mathrm{dS} \cdot \mathrm{m}^{-1}$ compared with the control. However, when irrigated with a saline solution of 10.0 $\mathrm{dS} \cdot \mathrm{m}^{-1}, V . \times$ burkwoodii, $V . \times{ }^{\prime} \mathrm{NCVX} 1$ ', and $V$. nudum 'Bulk' survived with a reduction in $\mathrm{P}_{\mathrm{n}}$ of $74 \%, 85 \%$, and $91 \%$, respectively (compared with the control). Salinity has been reported to decrease plant photosynthesis (Cirillo et al., 2016, 2019; Gómez-Bellot et al., 2015, 2018; Taiz et al., 2015). Compared with plants irrigated with a nutrient solution of $2.0 \mathrm{dS} \cdot \mathrm{m}^{-1}$, the $\mathrm{P}_{\mathrm{n}}$ of $V$. lucidum showed a reduction of $39 \%$ and $76 \%$, respectively, when irrigated with an $\mathrm{NaCl}$ solution of 11.1 and $20.5 \mathrm{dS} \cdot \mathrm{m}^{-1}$ (Cirillo et al., 2016, 2019). When irrigated with a saline solution of $6.0 \mathrm{dS} \cdot \mathrm{m}^{-1}$ for 6 months, the $\mathrm{P}_{\mathrm{n}}$ of $V$. tinus decreased by $33 \%$ compared with plants irrigated with water $\left(\mathrm{EC}<0.9 \mathrm{dS} \cdot \mathrm{m}^{-1}\right)$ (Gómez-Bellot et al., 2018). However, in another study, the $\mathrm{P}_{\mathrm{n}}$ of $V$. tinus did not change when irrigated with reclaimed water at an EC of $4.0 \mathrm{dS} \cdot \mathrm{m}^{-1}$ for 11 weeks, and subsequently with reclaimed water of 6.0 $\mathrm{dS} \cdot \mathrm{m}^{-1}$ for 25 weeks (Gómez-Bellot et al., 2015). This latter study may indicate that $V$. tinus increases its salinity tolerance through acclimation during a period in which it is irrigated with moderate-salinity irrigation water. The discrepancy in the decrease of the $\mathrm{P}_{\mathrm{n}}$ mentioned earlier could be attributed to initial (and variable) substrate EC in the plant root zone/substrate among the studies referenced. In addition, the $\mathrm{P}_{\mathrm{n}}$ values of viburnum plants at the first harvest were greater than those at the second harvest $(P<0.0001)$ (Table 1). It is not a surprise that substrate salinity levels increased as the duration of irrigation with saline solution increased. This factor may explain the reduced $P_{n}$ at the second harvest (Sun et al., 2015, 2020).

A salinity-induced decrease in the $P_{n}$ ultimately impacts plant biomass accumulation. In our study, there was a positive correlation between the $P_{n}$ and shoot dry weight at the first harvest $(P=0.007)$, whereas no correlation was found at the second harvest $(P=0.4)$ (data not shown). Cai et al. (2014) observed that, among 10 Rosa hybrida (garden rose) cultivars, 'Belinda's Dream' and 'Climbing Pinkie' irrigated with a saline solution of $10.0 \mathrm{dS} \cdot \mathrm{m}^{-1}$ had a similar $\mathrm{P}_{\mathrm{n}}$ to the control $\left(\mathrm{EC}=1.2 \mathrm{dS} \cdot \mathrm{m}^{-1}\right)$, but the Pn of other cultivars decreased. They also found that these two cultivars experienced much less shoot growth reduction than other cultivars (Cai et al., 2014). Wu et al. (2016) found that Scabiosa columbaria (butterfly flower), Lobelia cardinalis (cardinal flower), Caryopteris $\times$ clandonensis 'Dark Knight' (bluebeard), and Anisacanthus quadrifidus (flame acanthus) had a decreased $P_{n}$ by $31 \%$ to $60 \%$ and shoot dry weight by $46 \%$ to $70 \%$ when irrigated with a saline solution of $10.0 \mathrm{dS} \cdot \mathrm{m}^{-1}$. These results indicate that salinity inhibited plant photosynthesis and produced less biomass, regardless of taxa, when a salinity threshold was reached.

At the first harvest, compared with the control, $V$. cassinoides 'SMNVCDD', $V$. dentatum 'Christom', $V$. dentatum var. deamii 'SMVDLS', $V$. dilatatum 'Henneke', $V$. nudum 'Bulk', V. opulus 'Roseum', $V$. plicatum var. tomentosum 'Summer Snowflake', and $V$. xrhytidophylloides 'Redell' irrigated with a saline solution of $5.0 \mathrm{dS} \cdot \mathrm{m}^{-1}$ exhibited $29 \%$ to $63 \%$ reductions in the $g_{\mathrm{S}}$, whereas the other viburnum taxa had a $g_{\mathrm{S}}$ similar to the control (Table 2). Compared with the control, the $g_{\mathrm{S}}$ of all viburnum taxa was reduced by $47 \%$ to $83 \%$ when irrigated with a saline solution of $10.0 \mathrm{dS} \cdot \mathrm{m}^{-1}$. At the second harvest, the $g_{\mathrm{S}}$ of all viburnum taxa irrigated with a saline solution of $5.0 \mathrm{dS} \cdot \mathrm{m}^{-1}$ was similar to that of the control, except $V$. pragense 'Decker' and $V$. $\times$ rhytidophylloides 'Redell', which showed a 59\% and $61 \%$ decrease in the $g_{\mathrm{S}}$, respectively. When irrigated with a saline solution of $10.0 \mathrm{dS} \cdot \mathrm{m}^{-1}$, the $g_{\mathrm{S}}$ of $V$. $\times$ burkwoodii and $V$. nudum 'Bulk' was reduced by $60 \%$ and $88 \%$, respectively, compared with the control, but this was not the case for $V . \times^{\prime} \mathrm{NCVX}^{\prime}$ '. 
Table 2. Stomatal conductance $\left(g_{\mathrm{S}}\right)$ of 12 viburnum taxa irrigated with a nutrient solution [electrical conductivity $(\mathrm{EC})=1.3 \mathrm{dS} \cdot \mathrm{m}^{-1} ;$ control] or a saline solution $\left[\mathrm{EC}=5.0 \mathrm{dS} \cdot \mathrm{m}^{-1}(\mathrm{EC} 5)\right.$ or $\left.10.0 \mathrm{dS} \cdot \mathrm{m}^{-1}(\mathrm{EC} 10)\right]$ in a greenhouse. ${ }^{\mathrm{z}}$

\begin{tabular}{|c|c|c|c|c|c|c|}
\hline \multirow{2}{*}{ Taxa } & \multicolumn{6}{|c|}{$g_{\mathrm{S}}, \mathrm{mmol} \mathrm{H} \mathrm{H}_{2} \mathrm{O} \cdot \mathrm{m}^{-2} \cdot \mathrm{s}^{-1}$} \\
\hline & \multicolumn{3}{|c|}{ First harvest } & \multicolumn{3}{|c|}{ Second harvest } \\
\hline Viburnum $\times$ burkwoodii & $125.8 \mathrm{a}^{\mathrm{y}}$ & $102.2 \mathrm{ab}$ & $60.7 \mathrm{~b}$ & $76.0 \mathrm{a}$ & $53.9 \mathrm{ab}$ & $30.5 \mathrm{~b}$ \\
\hline V. dentatum 'Christom' & $151.3 \mathrm{a}$ & $106.8 \mathrm{~b}$ & $78.3 \mathrm{~b}$ & $119.9 \mathrm{a}$ & $78.8 \mathrm{a}$ & - \\
\hline V. dentatum var. deamii 'SMVDLS' & $236.7 \mathrm{a}$ & $117.7 \mathrm{~b}$ & $89.8 \mathrm{~b}$ & $170.2 \mathrm{a}$ & $118.9 \mathrm{a}$ & - \\
\hline V. dilatatum 'Henneke' & $122.6 \mathrm{a}$ & $80.6 \mathrm{~b}$ & $-^{\mathrm{x}}$ & 136.0 & - & - \\
\hline$V . \times{ }^{\prime} \mathrm{NCVX1}$ ' & $75.0 \mathrm{a}$ & $58.0 \mathrm{ab}$ & $37.0 \mathrm{~b}$ & $119.7 \mathrm{a}$ & $59.0 \mathrm{a}$ & $37.6 \mathrm{a}$ \\
\hline V. plicatum var. tomentosum 'Summer Snowflake' & $312.3 \mathrm{a}$ & $158.2 \mathrm{~b}$ & $76.6 \mathrm{~b}$ & $187.0 \mathrm{a}$ & $136.6 \mathrm{a}$ & 一 \\
\hline V. pragense 'Decker' & $142.5 \mathrm{a}$ & $102.6 \mathrm{ab}$ & $75.2 \mathrm{~b}$ & $152.4 \mathrm{a}$ & $62.1 \mathrm{~b}$ & - \\
\hline V. $\times$ rhytidophylloides 'Redell' & 356.9 a & $149.9 \mathrm{~b}$ & $128.8 \mathrm{~b}$ & $223.3 \mathrm{a}$ & $88.0 \mathrm{~b}$ & - \\
\hline V. trilobum & $155.5 \mathrm{a}$ & $116.3 \mathrm{a}$ & - & $92.9 \mathrm{a}$ & $63.7 \mathrm{a}$ & - \\
\hline
\end{tabular}

${ }^{\mathrm{z}}$ Plants were harvested after the fourth irrigation (first harvest, four weeks after the initiation of treatment) and eighth irrigation (second harvest, nine weeks after the initiation of treatment).

${ }^{\mathrm{y}}$ Means with the same lowercase letters within a row and harvest date are not significantly different among treatments by Tukey's honestly significant difference test or between treatments with Student's $t$ test at $\alpha=0.05$.

${ }^{\mathrm{x}}$ Data were not collected due to plant death.

Table 3. Transpiration $(E)$ of 12 viburnum taxa irrigated with a nutrient solution [electrical conductivity $(E C)=1.3 \mathrm{dS} \cdot \mathrm{m}^{-1} ;$ control] or a saline solution $[\mathrm{EC}=5.0$ $\mathrm{dS} \cdot \mathrm{m}^{-1}(\mathrm{EC} 5)$ or $10.0 \mathrm{dS} \cdot \mathrm{m}^{-1}$ (EC 10)] in a greenhouse. ${ }^{\mathrm{z}}$

\begin{tabular}{|c|c|c|c|c|c|c|}
\hline \multirow[b]{3}{*}{ Taxa } & \multicolumn{6}{|c|}{$E, \mathrm{mmol} \mathrm{H}{ }_{2} \mathrm{O} \cdot \mathrm{m}^{-2} \cdot \mathrm{s}^{-1}$} \\
\hline & \multicolumn{3}{|c|}{ First harvest } & \multicolumn{3}{|c|}{ Second harvest } \\
\hline & Control & EC 5 & EC 10 & Control & EC 5 & EC 10 \\
\hline$\overline{\text { Viburnum } \times \text { burkwoodii }}$ & $2.7 \mathrm{a}^{\mathrm{y}}$ & $2.3 \mathrm{ab}$ & $1.6 \mathrm{~b}$ & $2.1 \mathrm{a}$ & $1.7 \mathrm{ab}$ & $1.0 \mathrm{~b}$ \\
\hline V. cassinoides 'SMNVCDD' & $3.5 \mathrm{a}$ & $2.2 \mathrm{~b}$ & $1.0 \mathrm{c}$ & $1.8 \mathrm{a}$ & $1.2 \mathrm{a}$ & - \\
\hline V. dentatum 'Christom' & $3.4 \mathrm{a}$ & $2.6 \mathrm{ab}$ & $2.0 \mathrm{~b}$ & $3.1 \mathrm{a}$ & $2.1 \mathrm{~b}$ & - \\
\hline V. dentatum var. deamii 'SMVDLS' & $4.2 \mathrm{a}$ & $2.8 \mathrm{ab}$ & $2.3 \mathrm{~b}$ & $3.2 \mathrm{a}$ & $3.1 \mathrm{a}$ & - \\
\hline V. dilatatum 'Henneke' & $3.1 \mathrm{a}$ & $2.3 \mathrm{~b}$ & $-^{x}$ & 3.3 & - & - \\
\hline$V . \times{ }^{\prime} \mathrm{NCVX} 1 '$ & $2.0 \mathrm{a}$ & $1.6 \mathrm{ab}$ & $1.1 \mathrm{~b}$ & $3.0 \mathrm{a}$ & $1.8 \mathrm{a}$ & $1.2 \mathrm{a}$ \\
\hline V. nudum 'Bulk' & $5.7 \mathrm{a}$ & $3.2 \mathrm{~b}$ & $1.9 \mathrm{c}$ & $2.8 \mathrm{a}$ & $2.1 \mathrm{ab}$ & $0.6 \mathrm{~b}$ \\
\hline V. opulus 'Roseum' & $4.3 \mathrm{a}$ & $2.6 \mathrm{~b}$ & $1.9 \mathrm{~b}$ & 2.5 & - & - \\
\hline V. plicatum var. tomentosum 'Summer Snowflake' & $4.7 \mathrm{a}$ & $3.2 \mathrm{ab}$ & $2.0 \mathrm{~b}$ & $4.2 \mathrm{a}$ & $3.5 \mathrm{~b}$ & - \\
\hline V. pragense 'Decker' & $3.1 \mathrm{a}$ & $2.3 \mathrm{ab}$ & $1.9 \mathrm{~b}$ & $3.6 \mathrm{a}$ & $2.0 \mathrm{~b}$ & - \\
\hline V. ×rhytidophylloides 'Redell' & $5.3 \mathrm{a}$ & $3.4 \mathrm{~b}$ & $2.9 \mathrm{~b}$ & $4.0 \mathrm{a}$ & $2.4 \mathrm{~b}$ & - \\
\hline V. trilobum & $3.7 \mathrm{a}$ & $3.0 \mathrm{a}$ & - & $2.7 \mathrm{a}$ & $1.9 \mathrm{a}$ & - \\
\hline
\end{tabular}

${ }^{\mathrm{z}}$ Plants were harvested after the fourth irrigation (first harvest, four weeks after the initiation of treatment) and eighth irrigation (second harvest, nine weeks after the initiation of treatment).

${ }^{\mathrm{y}}$ Means with the same lowercase letters within a row and harvest date are not significantly different among treatments by Tukey's honestly significant difference test or between treatments with Student's $t$ test at $\alpha=0.05$.

${ }^{\mathrm{x}}$ Data were not collected due to plant death.

Bañón et al. (2012) reported that the $g_{\mathrm{s}}$ of $V$. tinus at an EC of $6.0 \mathrm{dS} \cdot \mathrm{m}^{-1}$ was decreased by $36 \%$ compared with the plants irrigated with a nonsaline solution of $2.0 \mathrm{dS} \cdot \mathrm{m}^{-1}$. According to Gómez-Bellot et al. (2018), a saline solution of $6.0 \mathrm{dS} \cdot \mathrm{m}^{-1}$ reduced the $g_{\mathrm{S}}$ of $V$. tinus by $8 \%$ compared with the plants irrigated with water $\left(\mathrm{EC}<0.9 \mathrm{dS} \cdot \mathrm{m}^{-1}\right)$ in a 6 -month study. The $g_{\mathrm{S}}$ of $V$. lucidum irrigated with a $\mathrm{NaCl}$ solution of 11.1 and $20.5 \mathrm{dS} \cdot \mathrm{m}^{-1}$ was reduced by $34 \%$ and $73 \%$, respectively, compared with those irrigated with a nutrient solution of $2.0 \mathrm{dS} \cdot \mathrm{m}^{-1}$ (Cirillo et al., 2016, 2019).

These cumulative findings indicate that the $g_{\mathrm{S}}$ is affected by salinity levels of irrigation solution to various degrees over varying timelines. A reduced $g_{\mathrm{S}}$ has been reported for various ornamental plants when subjected to saline irrigation sources. The $g_{\mathrm{S}}$ of Malvaviscus arboreus (Turk's cap), Phlox paniculata 'John Fanick' (phlox), and P. paniculata 'Texas Pink' was reduced when irrigated with a saline solution of $10.0 \mathrm{dS} \cdot \mathrm{m}^{-1}$ (Sun et al., 2015). Liu et al. (2017) found that the
$g_{\mathrm{S}}$ of Diervilla rivularis 'G2X885411' (diervilla) was reduced by $74 \%$ when irrigated with a saline solution of $5.0 \mathrm{dS} \cdot \mathrm{m}^{-1}$ for 6 weeks, but that of Diervilla rivularis 'G2X88544' and Diervilla rivularis 'Smndrsf' was unaffected. The duration of salinity stress imposed on plants also affects the $g_{S}$. In this study, all viburnum taxa at the first harvest had a greater $g_{\mathrm{S}}$ than those at the second harvest $(P=0.0003)$ (Table 2$)$, which might result from accumulated salt levels in the substrate (Sun et al., 2020). Liu et al. (2017) found that the $g_{\mathrm{S}}$ of Forsythia xintermedia 'Mindor' (border forsythia) did not change when irrigated with a saline solution of $5.0 \mathrm{dS} \cdot \mathrm{m}^{-1}$ for 6 weeks, but did decline after 9 weeks of irrigation with the same source.

At the first harvest, seven of the viburnum taxa irrigated with a saline solution of 5.0 $\mathrm{dS} \cdot \mathrm{m}^{-1}$ had a similar $E$ to that of the control, whereas $V$. cassinoides 'SMNVCDD', $V$. dilatatum 'Henneke', V. nudum 'Bulk', $V$. opulus 'Roseum', and $V$. ×rhytidophylloides 'Redell' had a decreased $E$ of $27 \%$ to $43 \%$ compared with the control (Table 3). A saline solution of $10.0 \mathrm{dS} \cdot \mathrm{m}^{-1}$ reduced the $E$ of all taxa by $39 \%$ to $72 \%$ compared with the control. At the second harvest, $V$. dentatum 'Christom', V. plicatum var. tomentosum 'Summer Snowflake', V. pragense 'Decker', and $V$. $\times$ rhytidophylloides 'Redell' irrigated with a saline solution of $5.0 \mathrm{dS} \cdot \mathrm{m}^{-1}$ exhibited a lower $E$ compared with the control, but the remaining six viburnum taxa had an $E$ value similar to the control. At an EC of $10.0 \mathrm{dS} \cdot \mathrm{m}^{-1}$, $V$. $\times$ burkwoodii and $V$. nudum 'Bulk' also had a lower $E$. An $\mathrm{NaCl}$ solution of $11.1 \mathrm{dS} \cdot \mathrm{m}^{-1}$ decreased the $E$ of $V$. lucidum by $28 \%$ (Cirillo et al., 2019). Similar trends occurred in $C$. $\times$ clandonensis 'Dark Knight', $F$. Xintermedia 'Mindor', Hibiscus syriacus 'ILVOPS' (rose of Sharon), Hydrangea macrophylla 'Smhmtau' (hydrangea), Parthenocissus quinquefolia 'Troki' (virginia creeper), and $S$. columbaria, which showed a decreased $E$ when salinity levels increased from 1.3 to $10.0 \mathrm{dS} \cdot \mathrm{m}^{-1}$ (Liu et al., 2017; Wu et al., 2016). Salinity effects on $E$ are likely different among taxa, yet that does not negate 
Table 4. Water used efficiency (WUE) of 12 viburnum taxa irrigated with a nutrient solution [electrical conductivity $(\mathrm{EC})=1.3 \mathrm{dS} \cdot \mathrm{m}^{-1}$; control] or a saline solution $\left[\mathrm{EC}=5.0 \mathrm{dS} \cdot \mathrm{m}^{-1}(\mathrm{EC} 5)\right.$ or $\left.10.0 \mathrm{dS} \cdot \mathrm{m}^{-1}(\mathrm{EC} 10)\right]$ in a greenhouse. ${ }^{\mathrm{z}}$

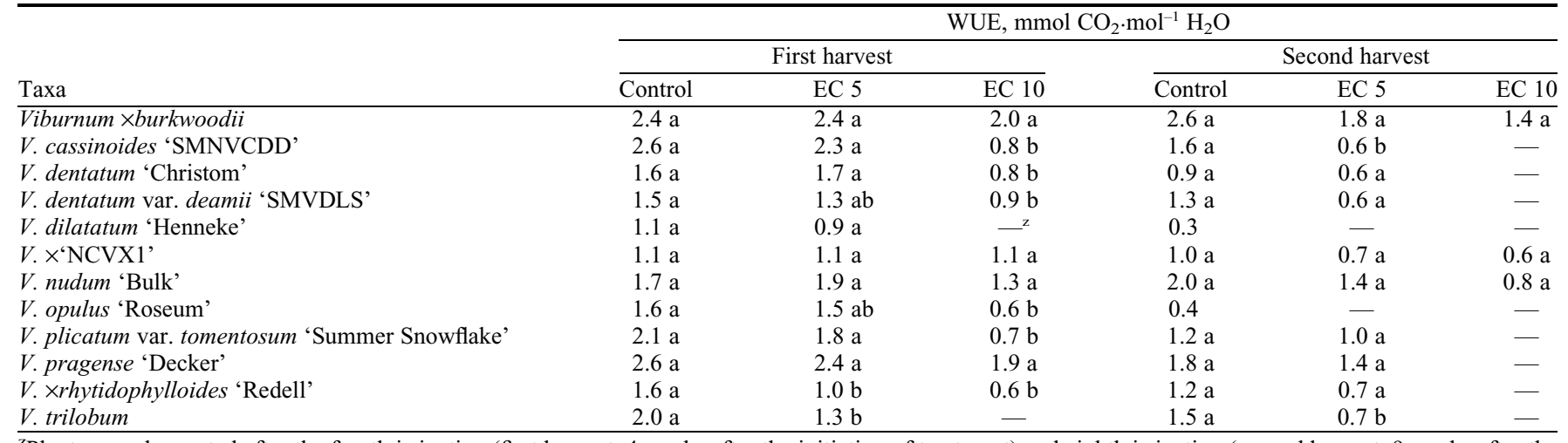

${ }^{\mathrm{z}}$ Plants were harvested after the fourth irrigation (first harvest, 4 weeks after the initiation of treatment) and eighth irrigation (second harvest, 9 weeks after the initiation of treatment).

${ }^{\mathrm{y}}$ Means with the same lowercase letters within a row and harvest date are not significantly different among treatments by Tukey's honestly significant difference test or between treatments with Student's $t$ test at $\alpha=0.05$.

${ }^{\mathrm{x}}$ Data were not collected due to plant death.

their impact on specific species or cultivars of ornamental plants. When salinity levels of irrigated solution increased from 1.1 to 10.0 $\mathrm{dS} \cdot \mathrm{m}^{-1}$, the $E$ of $P$. paniculata 'Texas Pink' decreased, but that of $P$. paniculata 'John Fanick' did not (Sun et al., 2015). Similar to $g_{\mathrm{S}}$, the $E$ of all viburnum taxa observed in our study decreased at the second harvest compared with the first harvest $(P=0.02)$ (Table $3)$. The increased (cumulative) salinity levels in the substrate might have led to the decreased $E$ observed for viburnum taxa in our study (Sun et al., 2020).

At the first harvest, all viburnum taxa irrigated with a saline solution of $5.0 \mathrm{dS} \cdot \mathrm{m}^{-1}$ had a WUE similar to the control except for $V$. ×rhytidophylloides 'Redell' and $V$. trilobum (Table 4). Viburnum cassinoides 'SMNVCDD', $V$. dentatum 'Christom', $V$. dentatum var. deamii 'SMVDLS', $V$. opulus 'Roseum', $V$. plicatum var. tomentosum 'Summer Snowflake', and $V$. ×rhytidophylloides 'Redell' had reduced WUE when irrigated with a saline solution of $10.0 \mathrm{dS} \cdot \mathrm{m}^{-1}$. However, under the same salinity regime, the WUE of $V$. ×burkwoodii, $V$. ×'NCVX1', $V$. nudum 'Bulk', and $V$. pragense 'Decker' was unchanged. At the second harvest, a saline solution of $5.0 \mathrm{dS} \cdot \mathrm{m}^{-1}$ decreased the WUE of $V$. cassinoides 'SMNVCDD' and $V$. trilobum, yet the remaining eight viburnum taxa did not change. Furthermore, no reduction in WUE was found in plants irrigated with the saline solution of $10.0 \mathrm{dS} \cdot \mathrm{m}^{-1}$. The WUE decreased at the second harvest compared with the first harvest $(P=0.0001)$, which aligned with our previous results for $\mathrm{P}_{\mathrm{n}}, g_{\mathrm{S}}$, and E. The WUE of Callistemon laevis (bottlebrush) also decreased when irrigated with a saline solution of $4.0 \mathrm{dS} \cdot \mathrm{m}^{-1}$ compared with those irrigated with a saline solution of $0.8 \mathrm{dS} \cdot \mathrm{m}^{-1}$ (Álvarez and SánchezBlanco, 2015).

\section{Mineral concentration}

Sodium. Saline solution irrigation affected leaf $\mathrm{Na}^{+}$concentrations in all viburnum taxa at both harvest dates in this study
$(P<0.0001$, Table 5). Compared with the control, leaf $\mathrm{Na}^{+}$concentration of $V$. dilatatum 'Henneke' and V. trilobum increased 22 times and 13 times, respectively, when irrigated with a saline solution of $5.0 \mathrm{dS} \cdot \mathrm{m}^{-1}$. The remaining 10 viburnum taxa still had leaf $\mathrm{Na}^{+}$concentrations similar to the control (Table 5). When irrigated with a saline solution of $10.0 \mathrm{dS} \cdot \mathrm{m}^{-1}$, leaf $\mathrm{Na}^{+}$concentration further increased for all viburnum taxa except for $V$. opulus 'Roseum'. Leaf $\mathrm{Na}^{+}$concentrations of $V$. $\times$ burkwoodii, $V$. cassinoides 'SMNVCDD', $V$. dentatum 'Christom', $V$. $\times$ 'NCVX1', $V$. nudum 'Bulk', $V$. pragense 'Decker', and $V . \times$ rhytidophylloides 'Redell' were 17 to 44 times greater than the control, whereas $V$. dentatum var. deamii 'SMVDLS', $V$. dilatatum 'Henneke', $V$. plicatum var. tomentosum 'Summer Snowflake', and $V$. trilobum leaf $\mathrm{Na}^{+}$concentrations increased by $74,147,61$, and 86 times, respectively, compared with the control. Viburnum dilatatum 'Henneke' (12.96 mg.g $\left.{ }^{-1}\right), V$. plicatum var. tomentosum 'Summer Snowflake' (8.17 $\left.\mathrm{mg} \cdot \mathrm{g}^{-1}\right)$, and $V$. trilobum $\left(7.64 \mathrm{mg} \cdot \mathrm{g}^{-1}\right)$ had relatively high leaf $\mathrm{Na}^{+}$concentrations, whereas the leaf $\mathrm{Na}^{+}$concentrations of $V$. $\times$ burkwoodii, $V$. dentatum 'Christom', $V$. nudum 'Bulk', and V. pragense 'Decker' were low (all leaf $\mathrm{Na}^{+}$concentrations $<3.00$ $\left.\mathrm{mg} \cdot \mathrm{g}^{-1}\right)$.

Excessive $\mathrm{Na}^{+}$accumulation in leaves causes foliar salt damage, and inhibits plant growth and photosynthesis. When leaf $\mathrm{Na}^{+}$ concentrations rose, the growth parameters, including visual score and height (both $P$ values $<0.001)$ decreased, but not the leaf area (Fig. 1). For the gas exchange parameters, $\mathrm{P}_{\mathrm{n}}, g_{\mathrm{S}}, E$, and WUE also decreased along with increasing leaf $\mathrm{Na}^{+}$concentration $(P<$ 0.002) (Fig. 2). Compared with plants irrigated with water at an EC of less than 0.9 $\mathrm{dS} \cdot \mathrm{m}^{-1}$, leaf $\mathrm{Na}^{+}$concentration of $V$. tinus irrigated with a saline solution of $6.0 \mathrm{dS} \cdot \mathrm{m}^{-1}$ for 6 months doubled, which resulted in a reduction in height, $\mathrm{P}_{\mathrm{n}}$, and $g_{\mathrm{S}}$ (Gómez-Bellot et al., 2018). Cirillo et al. (2016, 2019) also reported that $V$. lucidum irrigated with a $\mathrm{NaCl}$ solution of 11.1 and $20.5 \mathrm{dS} \cdot \mathrm{m}^{-1}$ had 12 and 5 times more $\mathrm{Na}^{+}$in the leaves compared with the plants irrigated with a nutrient solution of $2.0 \mathrm{dS} \cdot \mathrm{m}^{-1}$, which led to decreased plant height, shoot dry weight, leaf area, $\mathrm{P}_{\mathrm{n}}, g_{\mathrm{S}}$, and $E$. However, Cassaniti et al. (2009) found shoot $\mathrm{Na}^{+}$concentration of $V$. lucidum did not change when salinity levels of saline solution rose from 1.4 to $7.4 \mathrm{dS} \cdot \mathrm{m}^{-1}$. Furthermore, in our study, $V$. $\times$ burkwoodii and $V$. $\times$ 'NCVX1' had good visual quality without a reduction in shoot dry weight, despite increased shoot $\mathrm{Na}^{+}$ concentrations at an EC of $10.0 \mathrm{dS} \cdot \mathrm{m}^{-1}$. Similarly, leaf $\mathrm{Na}^{+}$concentration of Dicliptera suberecta (Mexican hummingbird bush), Cestrum 'Orange peel' (orange peel jessamine), and $P$. quinquefolia 'Troki' increased 9,5 , and 20 times when irrigated with a saline solution of $10.0 \mathrm{dS} \cdot \mathrm{m}^{-1}$, but their visual quality did not change (Liu et al., 2017; Wu et al., 2016). These results indicate these species are able to tolerate a high $\mathrm{Na}^{+}$concentration in their shoots. Some viburnum taxa may also have this ability, based on the results of our study.

Chloride. Leaf $\mathrm{Cl}^{-}$concentration was affected by saline solution irrigation $(P<$ 0.0001 , Table 5). When irrigated with a saline solution of $5.0 \mathrm{dS} \cdot \mathrm{m}^{-1}, V$. cassinoides 'SMNVCDD', $V$. dentatum 'Christom', $V$. dilatatum 'Henneke', V. nudum 'Bulk', $V$. pragense 'Decker', and $V$. trilobum accumulated 7 to 29 times more leaf $\mathrm{Cl}^{-}$ions than the control, and other viburnum taxa exhibited similar leaf $\mathrm{Cl}^{-}$concentration increases compared with the control (Table 5). A saline solution of $10.0 \mathrm{dS} \cdot \mathrm{m}^{-1}$ increased leaf $\mathrm{Cl}^{-}$ concentration in all viburnum taxa, which was 16 to 56 times greater than the control. Similar to foliar $\mathrm{Na}^{+}$concentration, leaf $\mathrm{Cl}^{-}$ concentration was high in $V$. dilatatum 'Henneke' (49.63 mg. $\left.\mathrm{g}^{-1}\right)$, V. plicatum var. tomentosum 'Summer Snowflake' (31.04 mg. ${ }^{-1}$ ), $V$. trilobum $\left(30.61 \mathrm{mg} \cdot \mathrm{g}^{-1}\right)$, and $V$. $\times$ 'NCVX1' (27.63 mg.g $\left.{ }^{-1}\right)$. Conversely, the lowest leaf $\mathrm{Cl}^{-}$concentration was in $V$. $\times$ burkwoodii (11.09 $\mathrm{mg} \cdot \mathrm{g}^{-1}$ ). Leaf $\mathrm{Cl}^{-}$concentration correlated negatively with visual 
Table 5. Leaf sodium $\left(\mathrm{Na}^{+}\right)$, chloride $\left(\mathrm{Cl}^{-}\right)$, potassium $\left(\mathrm{K}^{+}\right)$, and calcium $\left(\mathrm{Ca}^{2+}\right)$ concentration as well as the ratio of $\mathrm{K}^{+}$and $\mathrm{Na}^{+}\left(\mathrm{K}^{+} / \mathrm{Na}^{+}\right)$and the ratio of Ca ${ }^{2+}$ and $\mathrm{Na}^{+}\left(\mathrm{Ca}^{2+} / \mathrm{Na}^{+}\right)$of 12 viburnum taxa irrigated with a nutrient solution [electrical conductivity (EC) of $1.3 \mathrm{dS} \cdot \mathrm{m}^{-1}$ (control)] or a saline solution [EC of $5.0 \mathrm{dS} \cdot \mathrm{m}^{-1}$ (EC 5) or $\left.10.0 \mathrm{dS} \cdot \mathrm{m}^{-1}(\mathrm{EC} 10)\right]$ in a greenhouse. ${ }^{\mathrm{z}}$

\begin{tabular}{|c|c|c|c|c|c|c|c|}
\hline \multirow[b]{2}{*}{ Taxa } & \multirow[b]{2}{*}{ Treatment } & \multicolumn{6}{|c|}{ Ion concn $\left(\mathrm{mg} \cdot \mathrm{g}^{-1}\right)$} \\
\hline & & $\mathrm{Na}^{+}$ & $\mathrm{Cl}^{-}$ & $\mathrm{K}^{+}$ & $\mathrm{Ca}^{2+}$ & $\mathrm{K}^{+} / \mathrm{Na}^{+}$ & $\mathrm{Ca}^{2+} / \mathrm{Na}^{+}$ \\
\hline & EC 5 & $1.07 \mathrm{~b}$ & $2.88 \mathrm{~b}$ & $9.99 \mathrm{a}$ & $9.65 \mathrm{~b}$ & $12.77 \mathrm{~b}$ & $11.84 \mathrm{~b}$ \\
\hline & EC 10 & $2.91 \mathrm{a}$ & $11.09 \mathrm{a}$ & $10.53 \mathrm{a}$ & $12.95 \mathrm{a}$ & $3.76 \mathrm{~b}$ & $4.62 \mathrm{~b}$ \\
\hline & EC 5 & $1.24 \mathrm{~b}$ & $9.04 \mathrm{~b}$ & $9.51 \mathrm{~b}$ & $7.73 \mathrm{ab}$ & $9.17 \mathrm{~b}$ & $7.52 \mathrm{~b}$ \\
\hline & EC 10 & $3.45 \mathrm{a}$ & $16.91 \mathrm{a}$ & $12.02 \mathrm{a}$ & $10.65 \mathrm{a}$ & $3.79 \mathrm{~b}$ & $3.19 \mathrm{~b}$ \\
\hline$V$. dentatum 'Christom' & Control & $0.08 \mathrm{~b}$ & $0.45 \mathrm{c}$ & $11.91 \mathrm{~b}$ & $5.78 \mathrm{~b}$ & $146.57 \mathrm{a}$ & $71.24 \mathrm{a}$ \\
\hline \multirow[t]{3}{*}{ V. dentatum var. deamii 'SMVDLS' } & Control & $0.07 \mathrm{~b}$ & $0.36 \mathrm{~b}$ & $10.86 \mathrm{~b}$ & $6.38 \mathrm{~b}$ & $191.62 \mathrm{a}$ & $115.07 \mathrm{a}$ \\
\hline & EC 5 & $1.54 \mathrm{~b}$ & $6.26 \mathrm{~b}$ & $11.38 \mathrm{ab}$ & $7.56 \mathrm{ab}$ & $7.67 \mathrm{~b}$ & $5.21 \mathrm{~b}$ \\
\hline & EC 10 & $5.02 \mathrm{a}$ & $18.68 \mathrm{a}$ & $12.21 \mathrm{a}$ & $10.35 \mathrm{a}$ & $2.50 \mathrm{~b}$ & $2.05 \mathrm{~b}$ \\
\hline \multirow[t]{3}{*}{ V. dilatatum 'Henneke' } & Control & $0.09 \mathrm{c}$ & $1.79 \mathrm{c}$ & $13.39 \mathrm{~b}$ & $10.44 \mathrm{~b}$ & $152.60 \mathrm{a}$ & $119.04 \mathrm{a}$ \\
\hline & EC 5 & $2.05 \mathrm{~b}$ & $14.63 \mathrm{~b}$ & $12.95 \mathrm{~b}$ & $12.31 \mathrm{~b}$ & $39.46 \mathrm{~b}$ & $29.02 \mathrm{~b}$ \\
\hline & EC 10 & $12.96 \mathrm{a}$ & $49.63 \mathrm{a}$ & $17.50 \mathrm{a}$ & $25.55 \mathrm{a}$ & $1.37 \mathrm{~b}$ & $2.00 \mathrm{~b}$ \\
\hline$V . \times{ }^{\prime N C V X} 1$ ' & Control & $0.20 \mathrm{~b}$ & $0.72 \mathrm{~b}$ & $15.39 \mathrm{a}$ & $12.41 \mathrm{c}$ & $138.58 \mathrm{a}$ & $111.75 \mathrm{a}$ \\
\hline \multirow[t]{3}{*}{ V. opulus 'Roseum' } & Control & $0.09 \mathrm{a}$ & $0.52 \mathrm{~b}$ & $12.93 \mathrm{a}$ & $8.55 \mathrm{~b}$ & $147.34 \mathrm{a}$ & $97.47 \mathrm{a}$ \\
\hline & EC 5 & $0.83 \mathrm{a}$ & $5.05 \mathrm{~b}$ & $13.19 \mathrm{a}$ & $10.69 \mathrm{a}$ & $36.13 \mathrm{~b}$ & $30.89 \mathrm{~b}$ \\
\hline & EC 10 & $3.33 \mathrm{a}$ & $15.46 \mathrm{a}$ & $13.61 \mathrm{a}$ & $12.82 \mathrm{a}$ & $5.95 \mathrm{~b}$ & $5.25 \mathrm{~b}$ \\
\hline \multirow[t]{3}{*}{ V. plicatum var. tomentosum 'Summer Snowflake' } & Control & $0.13 \mathrm{~b}$ & $1.79 \mathrm{~b}$ & $15.99 \mathrm{a}$ & $7.47 \mathrm{~b}$ & $152.84 \mathrm{a}$ & $68.67 \mathrm{a}$ \\
\hline & EC 5 & $2.38 \mathrm{~b}$ & $11.20 \mathrm{~b}$ & $16.35 \mathrm{a}$ & $9.87 \mathrm{~b}$ & $7.30 \mathrm{~b}$ & $4.27 \mathrm{~b}$ \\
\hline & EC 10 & $8.17 \mathrm{a}$ & $31.04 \mathrm{a}$ & $16.61 \mathrm{a}$ & $18.28 \mathrm{a}$ & $2.10 \mathrm{~b}$ & $2.29 \mathrm{~b}$ \\
\hline \multirow[t]{3}{*}{$V$. pragense 'Decker' } & Control & $0.14 \mathrm{~b}$ & $0.57 \mathrm{c}$ & $14.13 \mathrm{a}$ & $7.48 \mathrm{~b}$ & $132.41 \mathrm{a}$ & $69.08 \mathrm{a}$ \\
\hline & EC 5 & $0.65 \mathrm{~b}$ & $4.30 \mathrm{~b}$ & $14.09 \mathrm{a}$ & $8.44 \mathrm{~b}$ & $37.27 \mathrm{ab}$ & $21.94 \mathrm{ab}$ \\
\hline & EC 10 & $2.58 \mathrm{a}$ & $11.36 \mathrm{a}$ & $14.16 \mathrm{a}$ & $11.04 \mathrm{a}$ & $5.65 \mathrm{~b}$ & $4.40 \mathrm{~b}$ \\
\hline \multirow[t]{3}{*}{ V. ×rhytidophylloides 'Redell' } & Control & $0.09 \mathrm{~b}$ & $0.54 \mathrm{~b}$ & $19.48 \mathrm{a}$ & $6.21 \mathrm{c}$ & $222.05 \mathrm{a}$ & $70.72 \mathrm{a}$ \\
\hline & EC 5 & $0.53 \mathrm{~b}$ & $6.11 \mathrm{~b}$ & $19.28 \mathrm{a}$ & $8.21 \mathrm{~b}$ & $124.34 \mathrm{ab}$ & $48.77 \mathrm{ab}$ \\
\hline & EC 10 & $3.96 \mathrm{a}$ & $17.20 \mathrm{a}$ & $18.72 \mathrm{a}$ & $10.96 \mathrm{a}$ & $8.08 \mathrm{~b}$ & $4.14 \mathrm{~b}$ \\
\hline V. trilobum & Control & $0.09 \mathrm{c}$ & $0.54 \mathrm{c}$ & $13.76 \mathrm{a}$ & $11.02 \mathrm{c}$ & $156.77 \mathrm{a}$ & $125.57 \mathrm{a}$ \\
\hline
\end{tabular}

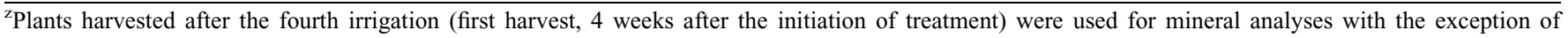
$V . \times{ }^{\prime} \mathrm{NCVX1}$ ', for which the leaves, harvested after the eighth irrigation (second harvest, 9 weeks after the initiation of treatment), were used. Therefore, analysis of variance was used to test the effects of salinity and taxa on mineral concentrations of all viburnum taxa except for $V$. $\times^{`} \mathrm{NCVX1}$, which was analyzed separately.

${ }^{\mathrm{y}}$ Means with the same lowercase letters within a viburnum taxon and dependent variable are not significantly different among treatments by Tukey's honestly significant difference test at $\alpha=0.05$.

$*, * *, * *$ Significant at $P<0.05,0.01$, or 0.001 , respectively.

score and height $(P<0.006)$, but not leaf area (Fig. 1). Leaf $\mathrm{Cl}^{-}$level also had negative correlations with $\mathrm{P}_{\mathrm{n}}, g_{\mathrm{S}}, E$, and WUE $(P<$ 0.0006) (Fig. 2).

When irrigated with a $\mathrm{NaCl}$ solution of 11.0 and $20.5 \mathrm{dS} \cdot \mathrm{m}^{-1}$ for 127 and $103 \mathrm{~d}$, respectively, $\mathrm{Cl}^{-}$concentration of $V$. lucidum was one and two times greater than the control $\left(\mathrm{EC}=2.0 \mathrm{dS} \cdot \mathrm{m}^{-1}\right)$ (Cirillo et al., 2016, 2019). Cirillo et al. $(2016,2019)$ also reported that plant height, shoot dry weight, leaf area, $\mathrm{P}_{\mathrm{n}}$, $g_{\mathrm{S}}$, and $E$ of $V$. lucidum decreased along with increasing leaf $\mathrm{Cl}^{-}$concentration. According to Gómez-Bellot et al. (2018) and Bañón et al. (2012), leaf $\mathrm{Cl}^{-}$concentration of $V$. tinus increased two and six times when irrigated with a saline solution of $6.0 \mathrm{dS} \cdot \mathrm{m}^{-1}$ compared with plants treated with water $\left(\mathrm{EC}<0.9 \mathrm{dS} \cdot \mathrm{m}^{-1}\right)$ and a nonsaline solution of $2.0 \mathrm{dS} \cdot \mathrm{m}^{-1}$, respectively, whereas plant height, dry weight, leaf area, $\mathrm{P}_{\mathrm{n}}$, and $g_{\mathrm{S}}$ were reduced along with increasing leaf $\mathrm{Cl}^{-}$at an $\mathrm{EC}$ of $6.0 \mathrm{dS} \cdot \mathrm{m}^{-1}$.
Similar to $V$. lucidum and $V$. tinus in those studies, all viburnum taxa in our study failed to tolerate high concentrations of $\mathrm{Cl}^{-}$ions in the shoots. However, Cassaniti et al. (2009) found that leaf $\mathrm{Cl}^{-}$concentration of $V$. lucidum did not increase when salinity levels of irrigation solution increased from 1.4 to $7.4 \mathrm{dS} \cdot \mathrm{m}^{-1}$. Similarly, $V$. ×burkwoodii had relatively low leaf $\mathrm{Cl}^{-}$ concentration with acceptable visual quality, indicating it may have the capability of excluding $\mathrm{Cl}^{-}$ions in shoots during saline solution irrigation events. This has been reported for Nerium oleander (oleander) and Buxus microphylla (Japanese boxwood) that had low leaf $\mathrm{Cl}^{-}$concentrations when irrigated with saline solutions at $5000 \mathrm{mg} \cdot \mathrm{L}^{-1} \mathrm{NaCl}(\mathrm{EC} \approx 7.8$ $\left.\mathrm{dS} \cdot \mathrm{m}^{-1}\right)$, indicating these plants might have the ability to exclude $\mathrm{Cl}^{-}$from being absorbed by the roots (Wu et al., 2001).

Potassium. Leaf $\mathrm{K}^{+}$concentrations were affected by saline solution irrigation $(P<$ 0.0001; Table 5). Compared with the control, leaf $\mathrm{K}^{+}$concentrations increased by $12 \%$ to $59 \%$ in $V$. cassinoides 'SMNVCDD', $V$. dentatum 'Christom', $V$. dentatum var. deamii 'SMVDLS', $V$. dilatatum 'Henneke', and $V$. nudum 'Bulk' irrigated with a saline solution of $10.0 \mathrm{dS} \cdot \mathrm{m}^{-1}$. Similarly, Gómez-Bellot et al. (2018) reported that leaf $\mathrm{K}^{+}$concentration of $V$. tinus irrigated with a saline solution of $6.0 \mathrm{dS} \cdot \mathrm{m}^{-1}$ was $51 \%$ greater than those irrigated with water at an EC of less than 0.9 $\mathrm{dS} \cdot \mathrm{m}^{-1}$. Salinity-induced increases in leaf $\mathrm{K}^{+}$ concentrations have been observed in other ornamental plants, including Chaenomeles speciosa 'Pink Storm' (flowering quince), Cuphea hyssopifolia (mexican false heather), D. rivularis 'G2X885411', 'G2X88544', 'Smndrsf', $F$. Xintermedia 'Mindor', $H$. syriacus 'ILVOPS', and P. paniculata 'John Fanick' (Liu et al., 2017; Sun et al., 2015; Wu et al., 2016). These species may have the ability to transport $\mathrm{K}^{+}$against the $\mathrm{Na}^{+}$gradient, which leads to an increase in leaf $\mathrm{K}^{+}$ 

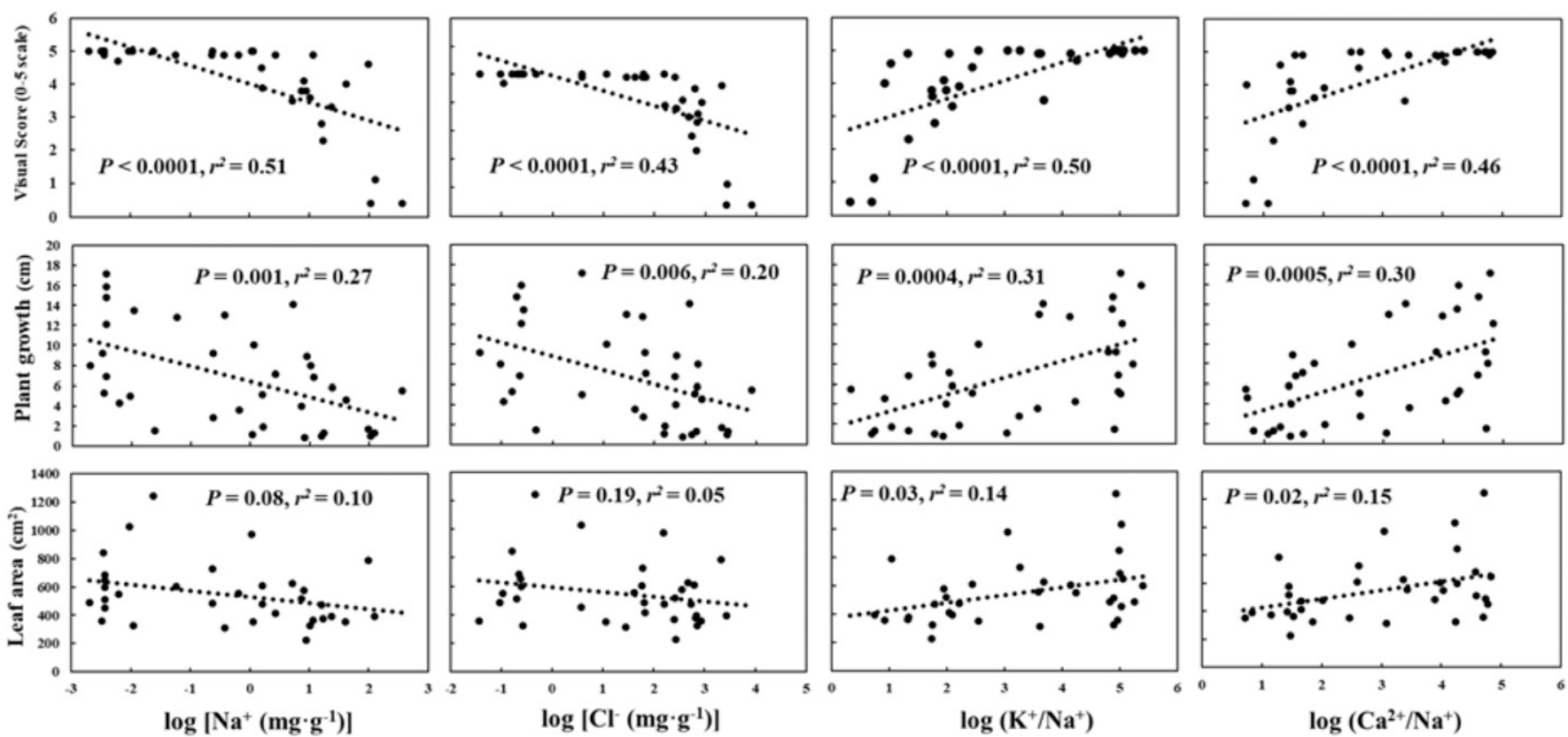

Fig. 1. Correlations between visual score, plant growth, leaf area, and leaf sodium $\left(\mathrm{Na}^{+}\right)$concentration, chloride $\left(\mathrm{Cl}^{-}\right)$concentration, the ratio of potassium $\left(\mathrm{K}^{+}\right)$to $\mathrm{Na}^{+}\left(\mathrm{K}^{+} / \mathrm{Na}^{+}\right)$, and the ratio of calcium $\left(\mathrm{Ca}^{2+}\right)$ to $\mathrm{Na}^{+}\left(\mathrm{Ca}^{2+} / \mathrm{Na}^{+}\right)$. The visual score used a 5-point scale: $0=$ dead, $1=$ severe foliar salt damage $(>90 \%$ leaves with burn and necrosis), $2=$ moderate foliar salt damage $(90 \%$ to $50 \%), 3=$ slight foliar salt damage $(<50 \%), 4=$ good quality with minimal foliar salt damage, and $5=$ excellent without foliar salt damage (Sun et al., 2015). Plant height was recorded at the beginning of the experiment and the two harvest dates. Plant growth was calculated as the differences between the initial height and the height at each harvest date. Log-transformed data of $\mathrm{Na}^{+}$concentration, $\mathrm{Cl}^{-}$ concentration, $\mathrm{K}^{+} / \mathrm{Na}^{+}$, or $\mathrm{Ca}^{2+} / \mathrm{Na}^{+}$were used for the correlation analyses.
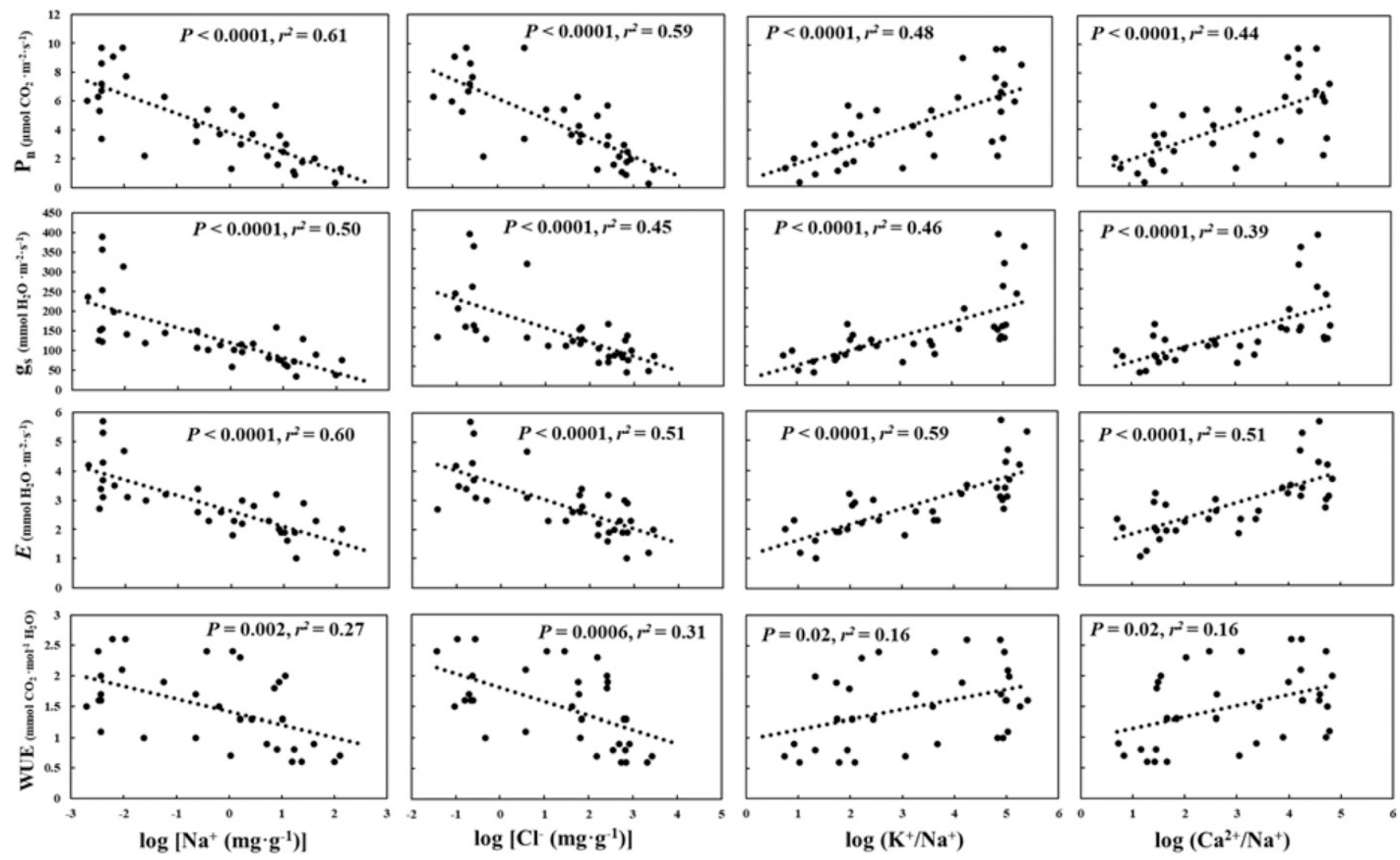

Fig. 2. Correlations between net photosynthesis rate $\left(\mathrm{P}_{\mathrm{n}}\right)$, stomatal conductance $\left(g_{\mathrm{S}}\right)$, transpiration rate $(\mathrm{E})$, water use efficiency (WUE), and leaf sodium $\left(\mathrm{Na} \mathrm{a}^{+}\right.$), chloride $\left(\mathrm{Cl}^{-}\right)$, the ratio of potassium $\left(\mathrm{K}^{+}\right)$to $\mathrm{Na}^{+}$, and the ratio of calcium $\left(\mathrm{Ca}^{2+}\right)$ to $\mathrm{Na}^{+}$. Log-transformed data of $\mathrm{Na}^{+}$concentration, $\mathrm{Cl}^{-}$concentration, $\mathrm{K}^{+} / \mathrm{Na}^{+}$, or $\mathrm{Ca}^{2+} / \mathrm{Na}^{+}$were used for the correlation analyses. 
accumulation, with a greater $\mathrm{K}^{+} / \mathrm{Na}^{+}$ratio under salinity stress (Grattan and Grieve, 1999). It might be a strategy for these five viburnum taxa to adapt to salinity stress by adjusting nutrient ratios to maintain the osmotic potential in a high-saline environment (Taiz et al., 2015).

The remaining seven viburnum taxa had similar leaf $\mathrm{K}^{+}$concentrations among three treatments (Table 5). These results are in contrast to previous findings indicating that leaf $\mathrm{K}^{+}$concentrations decrease as plants were subjected to increasing $\mathrm{Na}^{+}$environments (Sun et al., 2015; Valdez-Aguilar et al., 2009; Wu et al., 2016). This logic is well established, as $\mathrm{Na}^{+}$ions compete with $\mathrm{K}^{+}$ions for sites on transport proteins (Taiz et al., 2015), reducing plant growth and development. Cirillo et al. (2019) reported that leaf $\mathrm{K}^{+}$concentrations of $V$. lucidum were $29 \%$ and $28 \%$ less than those irrigated with a nutrient solution of $2.0 \mathrm{dS} \cdot \mathrm{m}^{-1}$, respectively, when irrigated with a $\mathrm{NaCl}$ solution of 11.1 $\mathrm{dS} \cdot \mathrm{m}^{-1}$ or a $\mathrm{CaCl}_{2}$ solution of $11.6 \mathrm{dS} \cdot \mathrm{m}^{-1}$ for $127 \mathrm{~d}$. The discrepancy between our results and these findings may correspond to varying durations of saline solution irrigation.

Moreover, the $\mathrm{K}^{+} / \mathrm{Na}^{+}$ratio decreased as salinity levels increased $(P<0.0001$; Table 5). The $\mathrm{K}^{+} / \mathrm{Na}^{+}$ratio of all viburnum taxa in the control was 2 to 25 times and 18 to 111 times as much as that irrigated with saline solutions of 5.0 and $10.0 \mathrm{dS} \cdot \mathrm{m}^{-1}$, respectively. These results are in line with previous reports on $V$. tinus (Gómez-Bellot et al., 2015) and $V$. lucidum (Cirillo et al., 2016, 2019). Positive correlations existed between the $\mathrm{K}^{+} / \mathrm{Na}^{+}$ratio and visual score, height, leaf area, $\mathrm{P}_{\mathrm{n}}, g_{\mathrm{S}}, E$, and WUE $(P<0.03)$ (Figs. 1 and 2). The $\mathrm{K}^{+} / \mathrm{Na}^{+}$ratio has been used to reflect plant salt tolerance (Gómez-Bellot et al., 2015). In our study, the $\mathrm{K}^{+} / \mathrm{Na}^{+}$ratio of $V$. dilatatum 'Henneke', $V$. plicatum var. tomentosum 'Summer Snowflake', and $V$. trilobum in the control was 111,73 , and 79 times as much as that at an EC of $10.0 \mathrm{dS} \cdot \mathrm{m}^{-1}$, and these taxa were considered the most saltsensitive taxa (Sun et al., 2020).

Calcium. In our study, leaf $\mathrm{Ca}^{2+}$ concentration was affected by saline solution irrigation $(P<0.0001$, Table 5). A saline solution of $5.0 \mathrm{dS} \cdot \mathrm{m}^{-1}$ increased leaf $\mathrm{Ca}^{2+}$ concentration in $V . \times$ 'NCVX1', $V$. nudum 'Bulk', $V$. opulus 'Roseum', V. ×rhytidophylloides 'Redell', and $V$. trilobum by $25 \%$ to $46 \%$ compared with the control (Table 5). Other tested viburnum taxa tended to increase leaf $\mathrm{Ca}^{2+}$ concentration, but not significantly. Leaf $\mathrm{Ca}^{2+}$ concentrations of all viburnum taxa irrigated with a saline solution of 10.0 $\mathrm{dS} \cdot \mathrm{m}^{-1}$ were $48 \%$ to $145 \%$ greater than the control. Similarly, V. tinus irrigated with a saline solution of $6.0 \mathrm{dS} \cdot \mathrm{m}^{-1}$ exhibited $21 \%$ greater leaf $\mathrm{Ca}^{2+}$ concentration than those irrigated with water at an EC of less than 0.9 $\mathrm{dS} \cdot \mathrm{m}^{-1}$ (Gómez-Bellot et al., 2018). However, the leaf $\mathrm{Ca}^{2+}$ concentration of $V$. lucidum did not change when irrigated with a $\mathrm{NaCl}$ solution of $11.1 \mathrm{dS} \cdot \mathrm{m}^{-1}$, but increased when irrigated with a $\mathrm{CaCl}_{2}$ solution of 11.6 $\mathrm{dS} \cdot \mathrm{m}^{-1}$ (Cirillo et al., 2019). The fact that the leaf $\mathrm{Ca}^{2+}$ concentration increased along with increasing salinity levels has been reported in many plant species, such as, $C$. speciosa 'Pink Storm', Cestrum 'Orange peel', $F$. ×intermedia 'Mindor', and P. paniculata 'John Fanick' (Liu et al., 2017; Sun et al., 2015; Wu et al., 2016). Although $\mathrm{Ca}^{2+}$ availability, uptake, and transport are impacted by $\mathrm{Na}^{+}$-dominated salinity stress (Grattan and Grieve, 1999), the increase of leaf $\mathrm{Ca}^{2+}$ concentration in our study may be attributed to $\mathrm{CaCl}_{2}$ being an ingredient of the prepared saline solution.

The $\mathrm{Ca}^{2+} / \mathrm{Na}^{+}$ratio has been used to study the capability of plants to discriminate between $\mathrm{Na}^{+}$and $\mathrm{Ca}^{2+}$ (Gómez-Bellot et al., 2015). In our study, the $\mathrm{Ca}^{2+} / \mathrm{Na}^{+}$ratio decreased as salinity levels increased $\left(P<0.0001\right.$, Table 5). The $\mathrm{Ca}^{2+}$ $/ \mathrm{Na}^{+}$ratio of all viburnum taxa in the control was 2 to 22 times and 16 to 59 times as much as those irrigated with saline solutions of 5.0 and $10.0 \mathrm{dS} \cdot \mathrm{m}^{-1}$, respectively. Similarly, GómezBellot et al. (2015) observed that the $\mathrm{Ca}^{2+} / \mathrm{Na}^{+}$ ratio of $V$. tinus irrigated with water at an $\mathrm{EC}$ of less than $0.9 \mathrm{dS} \cdot \mathrm{m}^{-1}$ was seven times those irrigated with a saline solution of $6.0 \mathrm{dS} \cdot \mathrm{m}^{-1}$. In addition, there were positive correlations between the $\mathrm{Ca}^{2+} / \mathrm{Na}^{+}$ratio and visual score, height, leaf area, $\mathrm{P}_{\mathrm{n}}, g_{\mathrm{S}}, E$, and WUE $(P<$ 0.02) (Figs. 1 and 2).

\section{Conclusions}

The $\mathrm{P}_{\mathrm{n}}, g_{\mathrm{S}}, E$, and WUE of viburnum taxa decreased, but leaf $\mathrm{Na}^{+}$and $\mathrm{Cl}^{-}$concentrations increased, with increasing salinity levels in the irrigation solution used in this study. Yet, plant growth responses varied among viburnum taxa. Leaf $\mathrm{Na}^{+}$and $\mathrm{Cl}^{-}$ concentrations correlated negatively with plant growth and gas exchange parameters. As excessive $\mathrm{Na}^{+}$ions accumulated in leaves, the uptake of $\mathrm{K}^{+}$and $\mathrm{Ca}^{2+}$ was affected negatively. The ratios of $\mathrm{K}^{+} / \mathrm{Na}^{+}$and $\mathrm{Ca}^{2+}$ $/ \mathrm{Na}^{+}$correlated positively with plant growth and gas exchange parameters. $V$. $\times$ burkwoodii and $V . \times{ }^{\prime} \mathrm{NCVX} 1$ ' had relatively less photosynthesis reduction and less $\mathrm{Na}^{+}$and $\mathrm{Cl}^{-}$ accumulation and foliar concentrations. This implies improved salt tolerance, indicating that both taxa had a better ability to exclude $\mathrm{Na}^{+}$and $\mathrm{Cl}^{-}$accumulation in the shoots to adapt to saline irrigation or sodic soils. However, other viburnum taxa tested in this study exhibited greater photosynthesis reduction and more $\mathrm{Na}^{+}$and $\mathrm{Cl}^{-}$ion accumulation, suggesting they are less tolerant to saline water irrigation.

\section{Literature Cited}

Álvarez, S. and M.J. Sánchez-Blanco. 2015. Comparison of individual and combined effects of salinity and deficit irrigation on physiological, nutritional and ornamental aspects of tolerance in Callistemon laevis plants. J. Plant Physiol. 185:65-74.

Bañón, S., J. Miralles, E. Conesa, J. Ochoa, J.A. Franco, and M.J. Sánchez-Blanco. 2012. Effects of salinity and boron excess on the growth, photosynthesis, water relation and mineral composition of laurustinus grown in greenhouse. Acta Hort. 927:379-384.
Beckerman, J. and B.R. Lerner. 2015. Salt damage in landscape plants. 13 Jan. 2020. <https:// www.extension.purdue.edu/extmedia/ID/ID-412W.pdf .

Cai, X., Y. Sun, T. Starman, C. Hall, and G. Niu. 2014. Response of 18 Earth-Kind ${ }^{\circledR}$ rose cultivars to salt stress. HortScience 49:544-549.

Cassaniti, C., C. Leonardi, and T.J. Flowers. 2009. The effects of sodium chloride on ornamental shrubs. Scientia Hort. 122:586-593.

Cirillo, C., V.D. Micco, C. Arena, P. Carillo, A. Pannico, S.D. Pascale, and Y. Rouphael. 2019. Biochemical, physiological and anatomical mechanisms of adaptation of Callistemon citrinus and Viburnum lucidum to $\mathrm{NaCl}$ and $\mathrm{CaCl}_{2}$ salinization. Front. Plant Sci. 10:742.

Cirillo, C., Y. Rouphael, R. Caputo, G. Raimondi, M.I. Sifola, and S.D. Pascale. 2016. Effects of high salinity and the exogenous application of an osmolyte on growth, photosynthesis, and mineral composition in two ornamental shrubs. J. Hort. Sci. Biotechnol. 91:14-22.

Daliakopoulos, I.N., I.K. Tsanis, A. Koutroulis, N.N. Kourgialas, A.E. Varouchakis, G.P. Karatzas, and C.J. Ritsema. 2016. The threat of soil salinity: A European scale review. Sci. Total Environ. 573:727-739.

García-Caparrós, P., A. Llanderal, M. Pestana, P.J. Correia, and M.T. Lao. 2016. Tolerance mechanisms of three potted ornamental plants grown under moderate salinity. Scientia Hort. 201:84-91.

Gavlak, R.G., D.A. Horneck, and R.O. Miller. 1994. Plant, soil, and water reference methods for the western region. Western Regional Extension Publication (WREP) 125.

Gómez-Bellot, M.J., P.A. Nortes, M.F. Ortuño, C. Romero, N. Fernández-García, and M.J. Sánchez-Blanco. 2015. Influence of arbuscular mycorrhizal fungi and treated wastewater on water relations and leaf structure alterations of Viburnum tinus L. plants during both saline and recovery periods. J. Plant Physiol. 188:96-105.

Gómez-Bellot, M.J., M.F. Ortuño, P.A. Nortes, A. Bernavé, F. Fernández, and M.J. SánchezBlanco. 2018. Effectiveness of bacterial inoculation in alleviation of salinity on water status, mineral content, gas exchange and photosynthetic parameters of Viburnum tinus L. plants. Scientia Hort. 237:303-310.

Grattan, S.R. and C.M. Grieve. 1999. Salinitymineral nutrient relations in horticultural crops. Scientia Hort. 78:127-157.

Havlin, J.L. and P.N. Soltanpour. 1980. A nitric acid plant tissue digest method for use with inductively coupled plasma spectrometry. Commun. Soil Sci. Plant Anal. 11:969-980.

Hooks, T. and G. Niu. 2019. Relative salt tolerance of four herbaceous perennial ornamentals. Horticulturae 5:36.

Isaac, R.A. and W.C. Johnson. 1975. Collaborative study of wet and dry ashing techniques for the elemental analysis of plant tissue by atomic absorption spectrophotometry. J. Assn. Offic. Anal. Chem. 58:436-440.

Kollmann, J. and P.J. Grubb. 2002. Viburnum lantana L. and Viburnum opulus L. (V. lobatum Lam., Opulus vulgaris Borkh.). J. Ecol. 90:1044-1070.

Liu, Q., Y. Sun, G. Niu, J. Altland, L. Chen, and L. Jiang. 2017. Morphological and physiological responses of ten ornamental taxa to saline water irrigation. HortScience 52:1816-1822.

Munns, R. 2002. Comparative physiology of salt and water stress. Plant Cell Environ. 25:239-250.

Munns, R. and M. Tester. 2008. Mechanisms of salinity tolerance. Annu. Rev. Plant Biol. 59: 651-681. 
Niu, G. and D.S. Rodriguez. 2006. Relative salt tolerance of selected herbaceous perennials and groundcovers. Scientia Hort. 110:352-358.

Pooler, M.R. 2010. 'Cree' and 'Nantucket' Viburnums. HortScience 45:1384-1385.

Sun, Y., J.J. Chen, H. Xing, A. Paudel, G. Niu, and M. Chappell. 2020. Growth, visual quality, and morphological responses of 12 Viburnum taxa to saline water irrigation. HortScience 55:12331241.

Sun, Y., G. Niu, and C. Perez. 2015. Relative salt tolerance of seven Texas Superstar ${ }^{\circledR}$ perennials. HortScience 50:1562-1566.
Taiz, L., E. Zeiger, I.M. Møller, and A. Murphy. 2015. Plant physiology and development. 6th ed. Sinauer Associates, Sunderland, MA.

Utah Division of Water Resources. 2005. Water reuse in Utah. Utah Department of Natural Resource, Salt Lake City, UT. 1 Jan. 2019. $<$ https://www.utah.gov/pmn/files/399007.pdf>.

Utah Division of Water Resources. 2014. Municipal and industrial water supply and use studies. Utah Department of Natural Resource, Salt Lake City, UT. 23 Dec. 2019. <https://water.utah.gov/ M\&I/PDF/State/2010\%20M_I\%20Statewide $\% 20$ SummaryCH.pdf>.
Valdez-Aguilar, L.A., C.M. Grieve, J. Poss, and D.A. Layfield. 2009. Salinity and alkaline $\mathrm{pH}$ in irrigation water affect marigold plants: II. Mineral ion relations. HortScience 44:17261735.

Wu, L., X. Guo, and A. Harivandi. 2001. Salt tolerance and salt accumulation of landscape plants irrigated by sprinkler and drip irrigation systems. J. Plant Nutr. 24:473-1490.

Wu, S., Y. Sun, G. Niu, J. Altland, and R.I. Cabrera. 2016. Response of ten aster species to saline water irrigation. HortScience 51:197201 . 